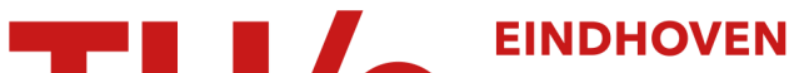 UNIVERSITY OF TECHNOLOGY
}

\section{Power supply noise monitor for signal integrity faults}

\author{
Citation for published version (APA): \\ Vazquez, J.R., \& Pineda de Gyvez, J. (2004). Power supply noise monitor for signal integrity faults. In \\ Proceedings of the Design, Automation and Test in Europe Conference and Exhibition, 2004, 16-20 February \\ 2004, Paris, France (Vol. 2, pp. 1406-1407). Institute of Electrical and Electronics Engineers. \\ https://doi.org/10.1109/DATE.2004.1269109
}

DOI:

10.1109/DATE.2004.1269109

Document status and date:

Published: 01/01/2004

\section{Document Version:}

Publisher's PDF, also known as Version of Record (includes final page, issue and volume numbers)

\section{Please check the document version of this publication:}

- A submitted manuscript is the version of the article upon submission and before peer-review. There can be important differences between the submitted version and the official published version of record. People interested in the research are advised to contact the author for the final version of the publication, or visit the $\mathrm{DOI}$ to the publisher's website.

- The final author version and the galley proof are versions of the publication after peer review.

- The final published version features the final layout of the paper including the volume, issue and page numbers.

Link to publication

\section{General rights}

Copyright and moral rights for the publications made accessible in the public portal are retained by the authors and/or other copyright owners and it is a condition of accessing publications that users recognise and abide by the legal requirements associated with these rights.

- Users may download and print one copy of any publication from the public portal for the purpose of private study or research.

- You may not further distribute the material or use it for any profit-making activity or commercial gain

- You may freely distribute the URL identifying the publication in the public portal.

If the publication is distributed under the terms of Article 25fa of the Dutch Copyright Act, indicated by the "Taverne" license above, please follow below link for the End User Agreement:

www.tue.nl/taverne

Take down policy

If you believe that this document breaches copyright please contact us at:

openaccess@tue.nl

providing details and we will investigate your claim. 


\section{Power Supply Noise Monitor for Signal Integrity Faults}

\author{
Josep Rius Vázquez \\ Departament d'Enginyeria Electrònica \\ Universitat Politècnica de Catalunya \\ Spain \\ email:rius@eel.upc.es
}

\author{
José Pineda de Gyvez \\ Digital Design and Test \\ Philips Research Laboratories \\ The Netherlands \\ email:jose.pineda.de.gyvez@philips.com
}

\begin{abstract}
We propose a monitor able to detect on-line excessive Power Supply Noise (PSN) at the power/ground lines. It has high resolution (100 ps), enough to collect the important features of PSN and its output is isolated from the local PSN. It is useful for any scheme that takes corrective actions to prevent signal integrity faults after detection of excessive PSN.
\end{abstract}

\section{Introduction}

Power supply noise (PSN) is a major concern in the design of modern ICs. Current spikes produced during the switching activity are transformed in voltage bounces in the supply lines. This transient reduction in the supply voltage decreases the gate drive strength, thus increasing the gate delay and lowering the circuit performance, thus producing potential delay faults [2], [3].

On-line monitoring of PSN appears as an interesting possibility to obtain information about the presence of excessive PSN to warn that a delay fault is likely to occur. This allows to a system controller to take corrective actions. Desirable features of such monitors are: (a) They should be located anywhere in the circuit to check the PSN in the local power/ground lines. (b) They should be able to check PSN at a given time (high time resolution). (c) They must be sensitive to PSN on supply and ground lines.

In this paper we describe a novel proposal on a monitor for PSN that fulfils the requirements above mentioned.

\section{PSN monitor circuit}

The main idea consists of measuring the power supply noise through its effect on the propagation delay of an inverter chain. Figure 1(a) shows the schematic of the proposed PSN monitor. The three inverters block works as a delay line, whose delay depends on its effective supply voltage. In synchronous systems, the PSN is triggered by the clock signal. Accordingly, the input of the delay line is connected to a signal derived from the clock line of the circuit.

The NOR gate works as a control gate to disconnect or test the monitor when desired. When the monitor is working, signal CTRL must be at " 0 ". Transistor MP1 works as a switch, which connects and disconnects capacitor $C_{Y}$ from the local supply line. Capacitor $C_{Y}$ must be large enough to keep the voltage $V_{Y}$ practically constant during the sampling process, thus isolating the monitor's output from the influence of $V_{D D}$ variations.

Transistors MP2 and MP3 work as switches connected in series between voltage $V_{Y}$ and capacitor $C_{X}$. When signal CK is at " 0 ", switch MP3 is open and MP2 is closed. Also, capacitor $C_{X}$ is discharged through $\mathrm{MN1}$ and voltage $V_{X}$ is zero. The rising edge of the clock line closes switch MP3 and a current begins to flow to capacitor $C_{X}$ increasing voltage $V_{X}$ (Figure 1(b)). This current charges the capacitor $C_{X}$ until the output signal of the inverter block changes, opening the switch MP2. Thus, the total charge supplied to $C_{X}$ is proportional to the propagation delay of the inverter block. As the propagation delay depends on the effective supply voltage seen by this block, the $V_{X}$ voltage at the end of the sampling period depends also on the supply voltage. As the power/ground bounce is produced just after the clock edge, the voltage $V_{X}$ will be dependent on the power/ground bounce: the higher the bounce is, the longer the propagation delay and the higher the voltage $V_{X}$ will be. Figure 1(b) shows the delays $t_{d 1}$ and $t_{d 2}$ due to two bounces in the supply voltage $\left(\mathrm{PSN}_{1}<\mathrm{PSN}_{2}\right)$. Voltage $V_{X}$ increases accordingly, and in this way the $V_{X}$ voltage is a sample of the effective supply voltage at the point where the monitor is connected.

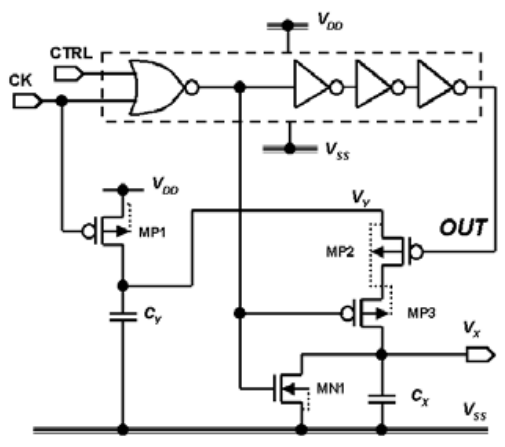

(a)

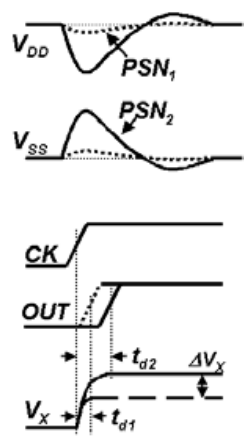

(b)
Figure 1. PSN monitor circuit.

The monitor samples the PSN during a time interval that is much smaller than the duration of the PSN [1]. The sensor sampling time corresponds to the moment when a rising edge is produced in the $\mathrm{CK}$ signal. By introducing a 
programmable delay line from the CK signal to the NOR input, we can change the sampling moment and obtain samples of the $V_{X}$ voltage at different times to check the PSN in the whole clock cycle.

In addition, we have included a simple and fast comparator that uses the threshold voltage of one inverter as a reference to detect excessive PSN. It consists of a first inverter with adjustable threshold with its input connected to $V_{X}$, a second inverter, which provides feedback to the first one, and a last inverter that provides a clean digital output.

\section{Simulations}

This section presents simulation results of the PSN monitor built in a $100 \mathrm{~nm}$ CMOS technology. The results show that the monitor behaves in agreement with the previous analysis. The test bench consists of generating simple dips in the supply voltage synchronised with the rising edge of the clock signal. The waveforms of the dips are trapezoids put over the nominal $V_{D D}$ and ground values. The delay between the dip and the clock edge, the dip width and the dip amplitude, are controlled to investigate the effect of these parameters on the monitor's behaviour. The dips are symmetrically applied to the power and the ground lines to check the correct behaviour of the monitor.

Figure 2 shows $\Delta V_{X}=V_{X}$ (with dip) - $V_{X}$ (without dip), that is to say, the increase in the $V_{X}$ voltage due to PSN. Simulations with fast, nominal and slow corners have been performed to obtain the sensitivity of the monitor response to process variations. As can be seen, the variability of $\Delta V_{X}$ is small, which highlights the monitor robustness. In this figure Vnoise is the sum of $V_{D D}$ and the GND dip/bump amplitudes.

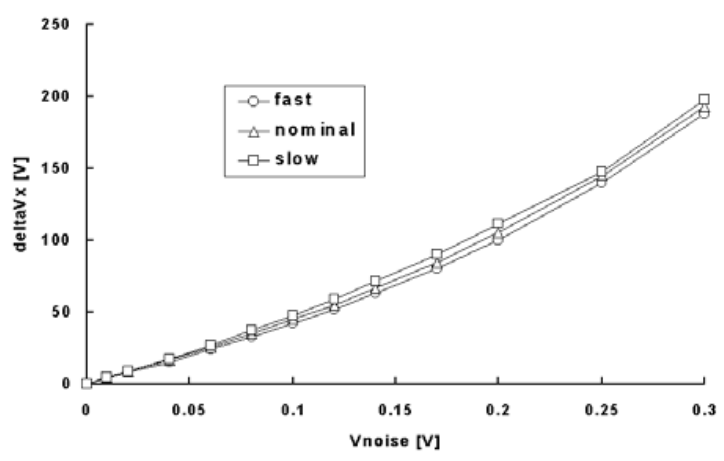

Figure 2. $\Delta \mathbf{V x}$ versus Vnoise for fast, nominal and slow process corners

Finally, figure 3 shows the clock, $V_{D D}$, ground, $V_{X}$ and VOUT waveforms. Clock frequency is $1 \mathrm{GHz}$, and a 100 $\mathrm{mV}$ PSN, $100 \mathrm{ps}$ wide is introduced in alternate clock cycles. As can be seen, the comparator's output (signal
VOUT) is activated (a zero pulse) only in the cycles where the noise is produced.

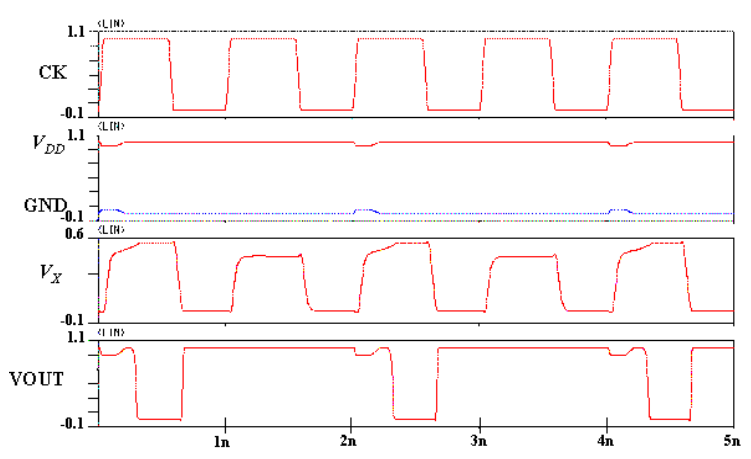

Figure 3. Monitor output for a clock frequency of 1 $\mathrm{GHz}$ and Vnoise $=100 \mathrm{mV}$

\section{Conclusions}

The PSN monitor described above is suitable for deep sub-micron technologies. It has the following features: (a) It can be located anywhere in the circuit and check the PSN in the local power/ground lines where the monitor is connected. (b) It has high resolution (100 ps), to collect the main features of the PSN in modern circuits. (c) It measures the PSN on supply and ground lines. (d) Its output is isolated from the PSN because it uses a locally generated "clean" power supply. (e) A high-level controller can easily change the sampling time, if required. (f) Control input allows selecting the desired clock cycle to measure PSN.

As the monitor is able to detect on-line the presence of excessive PSN, it can be used in any scheme that changes the operating circuit parameters to prevent signal integrity faults.

Acknowledgements: J. Rius acknowledges the support of the CICYT under projects TIC2001-2246, TIC200203127 and the Secretaría de Estado de Educación, Universidades, Investigación y Desarrollo in Spain.

\section{References}

[GAR02] B. Garben, R. Frech, J. Supper, M.F. McAllister, "Frequency Dependencies of Power Noise", IEEE Transactions on Advanced Packaging, VOL 25, No 2, May 2002, pp 166-173 [KRST01] A. Krstic, Y-M Jiang, K-T Cheng, "Pattern Gneration for Delay Testing and Dynamic Timing Analysis Considering Power Supply Noise Effects", IEEE Transactions on Computer Aided Design of Integrated Circuits and Systems, Vol. 20, No. 3, March 2001, pp. 416-425

[LIOU03] J-J Liou, A. Krstic, Y-M Jiang, K-T Cheng, "Modeling, Testing, and Analysis for Delay Defects and Noise Effects in Deep Submicron Devices", IEEE Transactions on Computer Aided Design of Integrated Circuits and Systems, Vol. 22, No. 6, June 2003, pp. 756-769 